\title{
Grey power and the economy: ageing and inflation across advanced economies
}

Article

Accepted Version

Vlandas, T. (2018) Grey power and the economy: ageing and inflation across advanced economies. Comparative Political Studies, 51 (4). pp. 514-552. ISSN 0010-4140 doi: https://doi.org/10.1177/0010414017710261 Available at https://centaur.reading.ac.uk/70761/

It is advisable to refer to the publisher's version if you intend to cite from the work. See Guidance on citing.

Published version at: http://journals.sagepub.com/doi/full/10.1177/0010414017710261

To link to this article DOI: http://dx.doi.org/10.1177/0010414017710261

Publisher: Sage

All outputs in CentAUR are protected by Intellectual Property Rights law, including copyright law. Copyright and IPR is retained by the creators or other copyright holders. Terms and conditions for use of this material are defined in the End User Agreement.

\section{www.reading.ac.uk/centaur}

\section{CentAUR}

Central Archive at the University of Reading

Reading's research outputs online 


\title{
GREY POWER AND THE ECONOMY:
}

\section{AGEING AND INFLATION ACROSS ADVANCED ECONOMIES}

\author{
Published in Comparative Political Studies \\ (This is the accepted/pre-proof version and therefore contains typos, etc. For a proofed version \\ please see the published version accessible at: \\ https://www.researchgate.net/publication/316156419 Grey power and the economy Ageing a \\ nd_inflation_across_advanced_economies)
}

Tim Vlandas ${ }^{1}$

t.r.g.vlandas@reading.ac.uk

Associate Professor in Political Economy, University of Reading

\begin{abstract}
What explains the cross-national variation in inflation rates across countries? In contrast to most literature, which emphasizes the role of ideas and institutions, this paper focuses on electoral politics and argues that ageing leads to lower inflation rates. Countries with a larger share of elderly exhibit lower inflation because older people are both more inflation averse and politically powerful, forcing parties seeking their votes to pursue lower inflation. Logistic regression analyses of survey data confirm that (1) older people are more inflation averse and (2) more likely to punish incumbents for inflation. Panel data regression analysis shows that (3) social democratic parties have more economically orthodoxy manifestos in European countries with more elderly people and that (4) the share of elderly is negatively correlated with inflation in both a sample of 21 OECD economies and a larger sample of 175 countries. Ageing therefore pushes governments to pursue lower inflation.
\end{abstract}

Keywords: Inflation, Ageing, Grey power, Economic policy, Independent Central Banks, Economic orthodoxy.

Word count: 13,449 .

${ }^{1}$ Acknowledgement: I am grateful for comments and discussion on this paper to Bob Hancke, David Soskice, Chiara Benassi, Abel Bojar, Michael Zemmour, Achim Goerres, Daphne Halikiopoulou, Margarita Gelepithis, Elvire Guillaud, Baptiste Francon, Jerome Bourdieu, Jonathan Golub, Julian Garritzmann, Marius Busemeyer and Marco Simoni. In November 2015, I received helpful comments when I was invited to present this paper at the University of Konstanz and at a workshop organized jointly by the Paris School of Economics and the University Paris 1 PantheonSorbonne. I also had very helpful discussions with James Reade about Error Correction Models. Abel Bojar kindly agreed that I use a dataset on individual voting behaviour in Europe which we are using in a separate joint project on economic voting and social groups. For excellent research assistance, I am thankful to Sergen Bahceci and Christos Vrakopoulos. Last but not least, I would also like to thank four reviewers and the editors of Comparative Political Studies for excellent constructive comments. All remaining errors are my own. 


\section{Introduction}

What explains the cross-national variation in inflation rates across developed countries? This question has been the subject of a large body of literature in both economics and comparative political economy. However, most studies to date have focused on the role of ideas, institutions, and economic factors (Cukierman, Web, \& Neyapti, 1992; Grilli, Masciandaro, Tabellini, Malinvaud, \& Pagano, 1991; Iversen, 1999; McNamara, 1998), and to a lesser extent interest groups (Posen, 1993, 1998), while paying insufficient attention to the role of electoral politics. The conventional wisdom captures part of the story for understanding variation in inflation rates, but the relative absence of electoral politics is surprising in two respects. First, this absence is at odds with the prominent role attributed to electoral politics in other political economy literature, for instance on labor market policies (Boix, 1998; Rueda, 2006; Vlandas, 2013a, 2013b) and the welfare state (Pierson, 1994, 1998). Second, inflation has identifiable distributive effects on different parts of the population which should therefore care about the level of inflation (Briault, 1995; Hibbs, 1979: pp. 712-715; Laidler, 1997; Scheve, 2004). Electoral politics may therefore make it possible to understand why certain ideas and institutions are chosen in the first place.

In this article, I seek to bring electoral politics back into the analysis of inflation by focusing on the preferences, power, and influence of a powerful social group: the elderly. This choice is motivated by both methodological and theoretical considerations. Methodologically, any analysis of the electoral determinants of inflation faces a problem of endogeneity. Many factors that affect the electorate's preferences for inflation such as wages, employment status, or assets may be partly endogenous to macroeconomic policy and inflation rates. Theoretically, the chosen social group needs to have clearly identifiable inflation preferences. 
As a first test of the role of electoral politics that minimizes both pitfalls, I choose to focus on the elderly — people aged 65 years and above. The elderly are clearly more inflation averse, and the share of elderly in a country is unlikely to be directly determined by inflation. Thus, the share of elderly is a good first case to investigate the impact of electoral preferences on inflation rates: It is highly correlated with factors that can be expected to influence inflation preferences but is not itself determined by inflation rates. The size of the elderly group across developed countries has also varied greatly over time, and the relevance of aging for welfare state policies has been well documented.

I argue that ageing has important consequences for economic outcomes as governments must increasingly take into account the economic policy preferences of the elderly. My theoretical framework builds on clear micro-foundations, conceptualizes several causal mechanisms, and then tests a number of observable implications. I posit that the elderly are more inflation averse because they are more indifferent to unemployment than the rest of the population, being outside of the labor market, but are concerned about the real value of their savings and pensions. As the size of this politically powerful group of voters increases, I expect that political parties increasingly compete to attract their votes before elections by adopting economically orthodox party manifestos, and that when in power, parties then pursue policies that contain inflation to minimize the risk of an electoral penalty at the next election. As a result, in countries with a larger share of elderly, parties are more economically orthodox, governments delegate monetary policy to independent central banks to a greater extent, and inflation is lower.

I test my argument in several steps. First, using logistic regression analysis of two separate surveys, I confirm that the elderly are more inflation averse. Second, using regression 
analysis of party manifesto data, I find that political parties in countries with a larger share of elderly have more economically orthodox party manifestos that emphasize price stability. The results are consistent with a "party competition" model where social democratic parties become more orthodox but not with a "party constituent" model where conservative parties respond to the growing weight of elderly among their constituents. Third, logistic regression analysis of survey data on past votes suggests that the elderly penalize the incumbent for higher inflation more than the rest of the population. Fourth, I show that the share of elderly is positively correlated with central bank independence (CBI) in a sample of 21 countries that are members of the Organization for Economic Cooperation and Development (OECD) in the period since 1960.

Next, I demonstrate that the share of elderly is negatively correlated with inflation rates in a sample of 21 OECD countries since 1960. My panel data regression analysis controls for competing explanations and the results hold using a wide variety of specifications and estimation methods. These findings are not biased by non-stationarity as they remain when I run pure crosssection, first difference, and error correction models (ECMs). When extending my analys is to a much larger sample of 175 countries for which data for the main variables are available, I find that the effect of the share of elderly on inflation only holds in democracies, thereby ruling out a purely economic effect linked to the elderly's economic behavior. This effect holds when excluding countries with high GDP per capita from the analysis, suggesting that my results are not an artifact of economic modernization where aging and low inflation occur jointly as a byproduct of economic development.

My findings have several wider implications. They show that aging has an important political impact on economic outcomes, and that electoral politics is a crucial factor in explaining 
the cross-national variation in inflation rates. Bringing electoral politics back in therefore helps us make sense of the continuing variation in inflation rates across countries with similar institutions and economies. This article further suggests that as countries age, achieving low inflation becomes an increasingly strong political imperative, regardless of what may be economically desirable.

The rest of the article enfolds as follows. The next section reviews previous literature and discusses my theoretical expectations. The second section then tests some of the causal mechanisms, while the third section tests the expectations of my model concerning the relationship between the share of elderly and inflation rates. The last section concludes with some implications for further research.

\section{The Political economy determinants of inflation rates}

\subsection{Ideas, institutions and interest groups}

Three main approaches in comparative political economy have sought to explain variation in inflation rates across developed economies over time. The first approach has focused on the role of ideas $^{2}$. In this approach, a new dominant economic narrative, new classical economics - and within it monetarism (Alt \& Chrystal, 1983; Friedman, 1968) - emerged as a response to the perceived inability of governments to address the stagflation of the 1970 s and convinced policy makers that any monetary induced employment gains over the long run fade away while resulting in higher inflation. This in turn made low inflation policies more appealing to government officials (e.g. Mc Namara 1998) and resulted in a shift away from the Keynesian

2 This short summary does not do justice to the sophistication of the argument - for a more comprehensive review, see Iversen \& Soskice, 2006. 
consensus that had prevailed in the post-war era until then (Hall, 1986).

The second approach focused on the role of institutions and how these may help solve the time inconsistency problem, namely how to achieve lower inflation when policy makers may be tempted, for electoral gains, to pursue short term goals that may raise inflation (Alesina, Rubini \& Cohen, 1999; Nordhaus, 1975; McRae, 1977). One solution to the time inconsistency problem that gained prominence was to partly or fully delegate monetary policy to independent central banks thereby convincing all actors that the commitment to low inflation was credible (Barro \& Gordon, 1983; Rogoff \& Sibert, 1988; Alesina, Mirrlees, \& Neumann, 1989). As a result, agents would expect low inflation and this in turn becomes a self-fulfilling prophecy, even in the absence of a monetary policy tightening (Grilli, Masciandaro, Tebellini, Malivaud \& Pagano, 1991). Independent central banks are expected to lead to lower inflation (Cuckierman, Webb \& Neyapti, 1992; Eijffinger \& de Haan, 1996; Debelle \& Fischer, 1994) because central banks are more conservatives - in the sense that they prefer lower inflation than elected governments - and less receptive to electoral pressures.

Both approaches are valuable in showing how various institutions and ideas affect inflation rates given certain interests in society. The problem with the ideational approach is what it leaves unanswered, namely whose ideas dominate policy making and why? ${ }^{3}$ In addition, most of this literature has been concerned with explaining the shift to a low inflation regime over time, making it difficult to use ideas to explain the cross-national variation in inflation rates we observe. To the extent that this literature focuses on the origins of these institutions, they are

\footnotetext{
${ }^{3}$ McNamara (1998) does discuss what made the new paradigm attractive: a combination of policy failure (in dealing with oil shock), policy innovation (monetarism) and policy emulation (seeing Germany as an example of good policy). Here I do not wish to suggest that these are irrelevant, rather that this must be completed by an analysis of electoral politics.
} 
either to be found in ideas or in the preferences of interest groups.

In addition to ideas and institutions, several interest groups with an influence on inflation have been identified. This third approach to explaining inflation has stressed the importance of wage bargaining, trade unions and the export sector (Franzese, 2003; Hall \& Franzese, 1998; Iversen, 1999). In the Keynesian era, unions moderated their wages in exchange for long term gains (Eichengreen 1996; Iversen and Soskice 2006). In countries with neo-corporatist institutions unions had greater incentives to exercise wage restraint because governments were offering them various welfare benefits in return (Cameron, 1984; Lange \& Garrett, 1985), thereby minimizing both inflation and unemployment if wage moderation was coupled with the right fiscal and monetary policies (Cf. Scharpf 1987). Union members lack sufficient power to influence inflationary outcomes in countries with highly decentralized wage bargaining at the firm level, while large encompassing trade unions internalize the inflationary effects of their wage claims (Calmfors \& Driffill 1988). Both arrangements should therefore result in lower inflation than where unions are strong but not encompassing. Finally, unions and employers in the export sector are inflation averse because they have a strong interest in retaining competitiveness, so countries with larger export sectors may exhibit lower inflation.

Moreover, Posen (1995) showed that, because of its preference for low inflation, the financial sector has a pivotal role in supporting price stability in the long run. Rather than being a cause of low inflation, he reasoned, central bank independence was itself determined by the financial sector's opposition to inflation. If this is true, both low inflation and central bank 
independence are more likely in countries with stronger financial actors ${ }^{4}$, whether because of lobbying on the parts of financial actors (Posen, 1995) or through the discipline of capital markets (Maxfield, 1997).

\subsection{Ageing and electoral politics}

While valuable, previous literature tends to neglect electoral politics, which had been the focus of older studies in comparative political economy. Indeed, four decades ago, Hibbs $(1977,1986)$ showed that electoral politics cannot be ignored because left-wing and right-wing parties have different inflation-employment preferences as their respective constituencies are differently affected by inflation and unemployment. When choosing institutions governments therefore cannot be assumed to entirely disregard electoral constraints, and even when institutions are already given, governments could still in principle influence inflation rates through other policies (e.g. fiscal policy, welfare state benefits, and wage policies).

However, focusing on left-right differences potentially overlooks changes in the electorate that may affect both left and right, in which case the effect would not necessarily operate via left-right differences in government partisanship. Over the long run, changes in the electorate's preferences may be more important than differences between different parts of the electorate at one point in time. Rather than focusing on partisan differences, the focus of this paper is on how different groups in the population may have distinct inflation preferences and how the size of these groups may in turn feed into differences in inflation rates across countries. Inflation has distributional consequences (Briault 1995; Fischer 1994; Laidler 1997), so different

\footnotetext{
${ }^{4}$ Cuckierman, Webb \& Neyapti (1992) similarly suggested that the likelihood of making central bank independents was a function of the size of financial markets and subsequent literature has by and large confirmed Posen's contention that central bank independence and low inflation requires political support to be sustained in the long run - see Berger, Eijffinger \& De Haan (2001), Hayo (1998), Kuttner \& Posen (2009), Miller (1998).
} 
groups should have different inflation preferences. One difficulty in estimating the effect of the electorate's preferences on inflation is that inflation may itself affect the characteristics of the electorate that shape their preferences. It is therefore crucial to use a criterion for identifying inflation averse groups that is as much as possible exogenous to inflation.

One such criterion is age. Here I focus in particular on the elderly, defined as those aged 65 years and over. ${ }^{5}$ Elderly people that are in retirement should care less (or not at all) about their employment prospect, since they derive their income from pensions and/or assets ${ }^{6}$ rather than employment, and are often net creditors, having repaid debts accumulated through mortgages $^{7}$. By contrast, the young and/or those in the labor force tend to care more about employment than inflation given that most of their income depends on working and that they are often net debtors (Bach and Stephenson 1974). The point here is not that inflation is entirely irrelevant for workers nor that employment is entirely irrelevant for those above 65, but rather that the elderly should care comparatively more about inflation than the non-elderly. I therefore expect older individuals to be more inflation averse.

Why does it matter what preferences elderly individuals hold? One answer is that developed economies have experienced a significant ageing of their population (Tepe \&

\footnotetext{
${ }^{5}$ Goerres 2009, pp 1-10, discusses the pros and cons of different cut-off points. For the purpose of minimizing the risk of capturing people who are not yet retired in our measure of inflation averse old people, it is safe to put the cutoff point at 65 .

${ }^{6}$ Elderly's preferences are relative: what matters is their inflation preferences relative to the rest of the population, and similarly for their position in terms of income sources, asset wealth, etc. The OECD shows that over-65s rely to a large extent on non-work sources of income such as public transfers or capital income in the 2000s (OECD 2013: page 78). The retired increasingly do not rely on inflation adjusted defined benefits pensions. Pension's benefits have become less generous in several countries and some defined pension schemes are not (or not sufficiently) inflation adjusted and hence inflation may still have adverse effects (OECD, 2013: 25). The elderly also have higher home ownership rate and derive a larger part of their income from capital, including non-inflation adjusted defined contribution schemes (ibid: 77-79). Estimates of the loss imposed by inflation over 20 years for non-inflation adjusted benefits are as large as one third (see Antolin, 2009).

${ }^{7}$ In most OECD countries more than 70\% of the over-65s own their houses - see OECD (2013: 77).
} 
Vanhuysse, 2009; Lynch \& Myrskylä, 2009; Sinn \& Uebelmesser, 2002). Almost 20\% of the population in the Euro area is above 65 , and $5 \%$ above 80 . The old age dependency ratio (share of $65+$ over those between 15 and 64) increased from $12.5 \%$ in 1950 to $23.8 \%$ in 2010 (European Commission, 2014, pp. 23). By 2050, the share of elderly may reach almost $30 \%$ in the European Union, with more than 10\% above 80 years old (European Commission, 2014, pp. 410). In sum, the elderly are a large and growing group in the population.

The elderly are a large group but this does not tell us how their preferences affect policies. There is a large literature in political economy that shows that individual preferences matter for policy outcomes (Rehm, 2016; Ansell, 2014; Rueda, 2006; Iversen \& Soskice 2001). In line with public choice theory, we might expect that as the share of elderly moves closer to $50 \%$ of the electorate, politicians will propose policies that reflect their preferences (Wilson, 1991). While they never represent $50 \%$ of national electorates, the elderly are not only a large and growing group, they are also a group with considerable political power (Rose, 1965, pp. 1314; Goerres, 2009; Sinn and Uebelmesser, 2002). Starting in the 1960s in the US the elderly "began to think of themselves as members of an aging group" and analysts at the time contended that the "elderly seem to be on their way to becoming a voting bloc" (Rose, 1965, pp. 13-14). In more recent times, older people in Europe are more likely to vote (Goerres 2007) and are much more likely to be members of political parties (Goerres 2009). People in the 60-69 age group are also more likely to be union members than every over age group except 50 to 59 years old (Goerres 2009, table 5.1). Even in a country where the share of the elderly is comparatively lower such as the US, they may yield considerable political power: they are more likely to vote than any other age group and also more likely to vote in all elections, they are more informed about politics and a more important source of campaign contributions (MacManus 2000, pp. 2, 3, 
7). In the 2012 US presidential election, the elderly accounted for as much as $22 \%$ of those who voted (File, 2014).

Given their growing size and power, this has raised the question of whether they have excessive control on the policy process. In the German case, some authors warn of the advent of gerontocracy (Sinn \& Uebelmesser, 2002, pp. 157) while in the US pensioner interest groups are seen to have significant lobbying power (Pampel \& Williamson, 1985; Pierson, 1994). The impact of ageing on policies has been most systematically studied in welfare state studies, which suggest that 'elderly power' matters for both welfare state expansion and retrenchment (Busemeyer, Goerres, \& Weschle., 2008; Esping-Andersen \& Sarasa, 2002; Lynch 2006; Sabbagh \& Vanhuysse, 2006). Previous research has in particular shown that spending on pensions is associated with a larger share of elderly (Persson \& Tabellini, 2000; IMF 2004; Mulligan \& Sala-i-Martin, 1999, 2003; Sinn \& Uebelmesser, 2002; Galasso, 2006; Galasso \& Profeta, 2007) because older and retired respondents are - not surprisingly - more supportive of pensions (Pamp, 2015, pp. 163). Conversely, they are less supportive of education (Sorensen, 2013) and hence US states with more elderly tend to spend less on education (Poterba, 1998; Fletcher \& Kenny, 2008; Harris, Evans \& Schwab, 2001).

While the association between the share of elderly and policies is therefore wellestablished, the mechanisms through which this association operates tend to be under-explored in quantitative research. Thus for instance, consistent with most literature, a recent study notes that "the particular ways in which social policy responsiveness [of governments to the elderly] is conditioned by factors such as ... electoral models, party politics, collective action problems, and institutional constraints...remain black boxes in our account" (Tepe \& Vanhuysse, 2010, pp. 
218-219). Where it is discussed, one links the growing size of the elderly to the ageing of the median voter, which can then using a median voter theorem be expected to lead to changes in policy. In these approaches, "the higher weight of older voters...shifts the median voter equilibrium" (Persson \& Tabellini, 2000, pp. 130).

\subsection{Ageing and inflation: a theoretical framework}

While the previous section suggests that we can expect the elderly to affect policy, what is missing for my purpose is an identification of the different possible mechanisms through which the growing share of elderly could influence inflation and of testable observable implications. I start from the premise that a defining feature of democracies is "congruence between citizen preferences and policy output" (Rehm, 2016, pp. 29). This assumption is reasonable in suggesting that governments respond to preferences but it does not specify why they respond and what they respond to. In what follows, I distinguish between two channels through which individual preferences in democracies can influence government policy.

In a first indirect electoral channel, individuals choose politicians that represent - and once elected, implement - their policy preferences. This is where it is necessary to consider party dynamics to identify the precise mechanisms linking individual preferences and parties in power. Within this indirect electoral channel, I distinguish between a 'party constituent' model and a 'party competition' model.

In the 'party constituent' model, political parties have long lasting commitments to certain parts of the electorate and/or to certain ideologies. A higher share of the elderly may mean that they have an increased influence on the political party that disproportionally represents them and/or that, for example, conservative parties having a pre-existing ideological 
commitment to low inflation find it easier to enact it when support among their constituents becomes sufficiently high as a result of the growing elderly electorate ${ }^{8}$. The elderly's party identification is higher than other groups (Butler \& Stokes, 1983; Goerres, 2009) and the evidence suggests that at least historically the elderly have been represented by conservative parties in several Western European countries. Thus for instance, the conservative party in the UK has historically been heavily supported by the elderly (Whiteley, Syed \& Richardson, 1994). If the conservative party becomes more inflation averse to reflect the growing size of inflation averse elderly people, we would expect a positive correlation between the inflation aversion of conservative parties and the share of elderly across countries. However, the evidence is mixed and in some countries the elderly might not predominantly support the conservative parties. For instance, in a more recent analysis, Goerres (2008) finds no evidence that older voters in Britain and Germany are more likely to vote for conservative parties. Conservative parties may also find it difficult to respond entirely to elderly constituents if this clashes with the demands of important younger and middle-aged groups (cf. Kitschelt, 2004, pp. 9-10).

In a 'party competition' model, political parties all compete for votes. One version of this model is that parties compete for the median voter. Previous literature has for instance used median voter models when assessing how ageing affects preferences for pension spending: as the median voter ages, she favors greater spending on pensions (Browning, 1975; Cooley \& Soares, 1999; Conesa \& Krueger, 1999; Persson \& Tabellini, 2000; Galasso, 2006; Galasso \& Profeta, 2007). Thus in my case, an ageing median voter becomes more inflation averse because the relative weight of her utility in old age, when she will no longer work and instead rely on fixed

${ }^{8}$ Here I implicitly draw on the distinction between opportunistic and compositional mechanisms discussed in Ansell (2014, pp. 12). 
income from assets and pensions, overtakes the weight of her utility in the present which depends on both employment opportunities and - in some cases - inflation protected wages. As the median voter becomes more inflation averse both parties have to become more inflation averse to acquire his/her electoral support. We would therefore expect a negative correlation between the age of the median voter, as proxied by the share of elderly, and the inflation aversion of all political parties on average and in particular of political parties that are forced to change their ideological position to meet their office seeking aspirations, most likely social democratic parties.

This latter model explicitly or implicitly underpins most literature on ageing and pension politics discussed earlier, and while median age for most countries across time is not available, most studies use the share of the elderly as a reasonable proxy for median age. It is also possible - and even more plausible in proportional representation systems - that political parties target a combination of large groups of constituents rather than just the median voter, in which case the share of the elderly is the more appropriate measure. Consistent with this, there is some evidence of party competition over the elderly vote. For instance, the Australian Labour party actively targeted the elderly vote in marginal seats, which in turn forced John Howard to change his policies on health care and pensions to win the 2004 federal election (Uren, 2007). Equally, New Labour's success in the UK was in large part due to its ability to attract elderly voters in the 1997 election (Tilley, 2002).

In the second - direct - channel, politicians "stay closely attuned to the ebb and flow of public opinion and adjust policy accordingly" when in power (Wlezien \& Soroka, 2007, pp. 805). There is a large and diverse literature on policy responsiveness which does convincingly 
show that changes in public opinion do lead to changes in public policy (Canes-Wrone 2015). There are two reasons for this: first, elected politicians want to minimize "civil disobedience and protests"; second, they want to minimize the risk of "electoral losses for themselves" (Brooks \& Manza, 2006, pp. 479). There is evidence for both an ex post and an ex ante process: elected governments who stray too far away from average opinion are punished if there is a challenger closer to public opinion (Hollibaugh, Rothenberg \& Rulison, 2013) and they internalize public opinion to pre-empt electoral losses (Erikson, MacKuen \& Stimson 2002; Page \& Shapiro 1983).

A similar intuition characterizes the economic voting literature but it considers macroeconomic outcomes rather than economic policies ${ }^{9}$. Individuals are seen to reward or punish governments in elections depending on economic performance, most notably unemployment and inflation. The research first analyzed popularity functions in the US and then later considered other advanced economies, as well as shifting the focus to actual aggregate votes $^{10}$. It soon also started investigating the impact of retrospective and prospective subjective evaluations of the economy (Norpoth, 1996 ; Erikson, MacKuen \& Stimson, 2000) as well as focusing more specifically on individual voting behavior. Overall, Lewis-Beck concludes that "changing economic conditions exert a force on Western European voters that approaches and sometimes exceeds the force of more traditional factors" (Lewis-Beck, 1988, pp. 85). Building on this literature, I argue that elderly voters penalize the incumbent for inflation to a greater extent than other social groups because they are more inflation averse. As a result, in countries with a larger share of elderly, incumbent parties should face a stronger electoral penalty for high

\footnotetext{
${ }^{9}$ For general overviews see Lewis-Beck et al. (2007), Norpoth (1996), Lewis-Beck \& Stegmaier (2000).

10 See Paldam (1991) for an early treatment of the determinants of vote change in 17 developed democracies.
} 
inflation than elsewhere and should therefore be more likely to pursue low inflation.

In sum, a growing share of inflation averse elderly people can theoretically be expected to influence government policy and inflation because (1) parties that traditionally represent them become more inflation averse to reflect their growing importance, (2) parties target an ageing and hence increasingly inflation averse median voter, (3) parties increasingly compete for elderly votes, (4) governments target an average public opinion that is becoming more inflation averse as a result of ageing, or (5) the elderly impose a larger electoral penalty on the incumbent for 'excessive' inflation and/or policies that increase inflation.

If they wish to reduce inflation, governments have several tools at their disposal. First, they can choose certain institutions that contain inflation, for instance by delegating monetary policy to politically independent central banks. Second, governments can pursue certain policies that contain inflation. Thus for instance, even when central banks are partly independent, governments can sometimes continue to pursue conservative anti-inflation monetary policies (Posen, 1995, pp. 254) and they can affect the supply of money by altering credit rules and capital requirements for banks ${ }^{11}$. In addition to monetary policy tools, governments can influence inflationary outcomes via fiscal policy, which in turn shapes aggregate demand, and they can intervene in the wage bargaining process ${ }^{12}$, set statutory minimum wages or affect the reservation wage through labor market benefits. Thus, governments have several tools at their disposal to influence inflationary outcomes. We can therefore expect countries with a larger share of elderly to have more inflation-averse political parties, governments that choose

11 This mechanism applied to a greater extent in the 1960s and 1970s - see for instance Zysman (1977) on France.

${ }^{12}$ For instance in France, the government extends wage agreements to most workers in a sector regardless of whether they are unionised. 
institutions which promote low inflation and that pursue policies which lower inflation more than other countries, and in turn these countries should exhibit lower inflation.

Finally, if the old have different levels of assets and distinct consumption and investment behaviors (Yoon, Kim \& Lee, 2014; Fair \& Dominguez, 1991, Lindh \& Malmberg, 2000, Bullard, Garriga \& Walker, 2012), then there may be an economic association between ageing and inflation. In this case, we should observe a correlation between ageing and low inflation in both democracies and non-democracies, since intermediation through the political system is not necessary. If the effect operates in the political arena only, the correlation should only hold in democracies and we should find evidence for the political mechanisms identified above.

\section{Microfoundations and causal mechanisms}

\subsection{Inflation aversion among the elderly}

To test my assumption concerning the elderly's inflation preferences, I rely on two surveys. The first is the International Social Survey Program (ISSP) on the Role of Government which includes four waves (1985, 1990, 1996 and 2006). I use two separate questions to derive my dependent variables. The first question is about whether controlling prices is government's responsibility where respondents can choose: 4-definitely should be, 3-probably should be, 2probably should not be, and 1-definitely should not be. The second question asks respondents to choose whether the government should "keep inflation down" or "keep unemployment down". My key independent variable is a dummy variable that takes value 1 if the respondent is elderly and 0 otherwise. I control for gender, years of schooling, country as well as time effects. 
The results from a logistic regression analysis are presented in table 1. Elderly respondents are more inflation averse: in column 1 I use a binary dependent variable equal to 1 if respondents choose that controlling prices "should definitely be" government's responsibility, and 0 otherwise; in column 2 the binary dependent variable equals 1 if respondents choose that controlling prices "definitely should be" or "probably should be" the government's responsibility; in column 3 I rely on the full ordinal variable using ordinal logistic regression analysis; and column 4 reports the results when my dependent variable 'Inflation down' takes value 1 if respondents choose "keep inflation down" and 0 if they choose "keep unemployment down”. Using age or being retired instead of being elderly does not change the results ${ }^{13}$ and my results are consistent with previous literature (Shiller, 1997, pp. 26, 27; Lelyveld, 1999, pp. 469, 476; Scheve, 2004, pp. 11).

Note that these results do not imply that the old have perfectly homogenous preferences, but merely that they are more likely to be inflation averse, ceteris paribus, than other age groups $^{14}$. I use being elderly and/or retired as an instrument that captures other variables that affect inflation aversion rather than as a factor that necessarily and intrinsically affects inflation aversion, so these results could a priori be consistent with both a life cycle and a generational effect, but it is possible to explore which effect is at work. The ISSP waves are too close in time to really delineate generational versus lifecycle effect so I use instead the Mannheim Eurobarometer Trend File (Schmitt, Scholz, Leim \& Moschner, 2008) covering the period 1970 to 2002 in 15 western European countries. My dependent variable is derived from a question

\footnotetext{
13 See Table A4 and Table A5 in appendix.

14 Similarly, there is a large literature (e.g. Boix 1998, Rueda 2006) that posits an impact of for instance labour market position on political preferences without necessarily implying that all individuals within a sub-category have totally homogenous preferences.
} 
about which issue respondents find most important, where they can choose their first and second priority from four possibilities: "maintenance of law and order", "giving people more say in government decision", “fighting rising prices", or "protecting freedom of expression".

Results shown in column 5 confirm that being elderly or retired is associated with a higher likelihood of identifying inflation as a first or second priority, when controlling for gender and education. Controlling for income or left-right placement and using a dependent variable that is coded 1 only if inflation is first priority does not change the results ${ }^{15}$. Rerunning the analysis on restricted samples covering only the 1970s, 1980s, and 1990s, respectively, shows that being retired and/or elderly is positively associated with higher inflation aversion in each decade ${ }^{16}$. This support for the life cycle hypothesis is consistent with previous findings on elderly preferences towards pension and education policies (De Mello, Schotte, Tiongson \& Winkler, 2016, pp. 6).

Table 1: The determinants of individual level inflation aversion

\begin{tabular}{lccccc}
\hline Dependent variable & $\begin{array}{c}(\mathbf{1}) \\
\text { Control } \\
\text { prices 1 }\end{array}$ & $\begin{array}{c}\text { Control } \\
\text { prices 2 }\end{array}$ & $\begin{array}{c}\text { (3) } \\
\text { Control } \\
\text { prices 3 }\end{array}$ & $\begin{array}{c}\text { (4) } \\
\text { Keep } \\
\text { inflation } \\
\text { down }\end{array}$ & $\begin{array}{c}\text { (5) } \\
\text { Inflation } \\
\mathbf{1}^{\text {st }} \text { or 2 } \\
\text { priority }\end{array}$ \\
\hline Regression method & Logit & Logit & Logit & Logit & Logit \\
\hline Elderly & $0.137^{* * *}$ & $0.193^{* * *}$ & $0.137 * * *$ & $0.077 \mathrm{t}$ & $0.235^{* * *}$ \\
\hline Constant & $0.566^{* * *}$ & $3.066^{* * *}$ & Several cuts & -0.016 & $1.659^{* * *}$ \\
Observations & 74,134 & 74,134 & 74,134 & 17,088 & 468,452 \\
Country fixed effects & Yes & Yes & Yes & Yes & Yes \\
Time effects & Yes & Yes & Yes & Yes & Yes \\
Pseudo R-squared & 0.08 & 0.09 & 0.06 & 0.05 & 0.10 \\
\hline
\end{tabular}

Note: $* * * p<0.001, * * p<0.01, * p<0.05, t p<0.1$. All columns control for education and gender. Column 3 uses ordinal logistic analysis on an ordinal dependent variable (constant cuts not shown - see appendix) while all other columns use normal logistic analysis on binary dependent variables. Columns 1 to 4 use the ISSP data. Using being 'retired' instead of being elderly does not change the results. Column 5 uses Eurobarometer data and is robust to the use of a dependent variable that is coded 1 if respondents

${ }^{15}$ See Tables A19 and A20 in appendix.

${ }^{16}$ See Table A21 in appendix. 
choose inflation as $1^{\text {st }}$ priority only and to the inclusion of income and/or a measure of left-right selfplacement. The variables elderly and retired are statistically significant at the $10 \%$ level when the Eurobarometer data is restricted to the 1970s, 1980s, or 1990s, respectively. See section 3.1 in appendix for more details on variables and robustness checks.

\subsection{Ageing and the economic orthodoxy of political parties}

Earlier I posited that the share of elderly could influence inflation by shaping the degree of inflation aversion among political parties competing in elections. There is to my knowledge no direct measure of anti-inflation preferences of all political parties in OECD countries. But the party manifesto dataset project (Volkens, Lehmann, Merz, Regel \& Werner, 2014), which codes all party manifestos along several dimensions since the 1950s, has a variable that comes close called 'Economic Orthodoxy' (per414). This variable captures whether the party manifesto refers to "support for a strong currency". It also captures factors that likely have an effect on inflation such as "reduction of budget deficits", and "thrift and savings in the face of economic hardship". Higher values mean that there are more references to economic orthodoxy in a given manifesto in a country's election.

Table 2 presents my results estimating the impact of the share of elderly on economic orthodoxy when controlling for inflation, trade openness, unemployment, deficits, and left cabinet seats ${ }^{17}$. In column 1 , my dependent variable captures the average across all political parties' manifestos in 10 years period average since the 1960s. This allows me to explore how a large group of voters that are opposed to inflation forces political parties to shift their policy preferences towards inflation. The results controlling for country fixed effects and time effects suggest that countries with more elderly as a percentage of the population exhibit more

17 See Table A24 in appendix for results with stepwise insertion of independent variables. 
economically orthodox political parties ${ }^{18}$.

Table 2: The share of elderly and economic orthodoxy in party manifesto

\begin{tabular}{lccc}
\hline Column & $(\mathbf{1})$ & $(\mathbf{2})$ & $(3)$ \\
\hline $\begin{array}{l}\text { Dependent variable } \\
\text { economic orthodoxy }\end{array}$ & All parties & $\begin{array}{c}\text { Social democratic } \\
\text { parties }\end{array}$ & $\begin{array}{c}\text { Gap between } \\
\text { conservative and social } \\
\text { democratic parties }\end{array}$ \\
\hline Period & $\mathbf{1 0}$ years & Yearly & Yearly \\
\hline Share of elderly & $0.186 \mathrm{t}$ & $0.187^{*}$ & $-1.024^{*}$ \\
\hline Inflation rate & $(0.096)$ & $(0.093)$ & $(0.337)$ \\
Trade openness & -0.005 & 0.023 & 0.055 \\
Unemployment rate & 0.012 & -0.006 & -0.021 \\
Deficit & 0.054 & 0.044 & $0.104^{* *}$ \\
Union density & 0.035 & $-0.108^{*}$ & 0.020 \\
Left cabinet seats & 0.007 & $0.054^{*}$ & 0.029 \\
\hline Constant & 0.009 & -0.002 & 0.014 \\
Observations & -0.750 & $-2.910 \mathrm{t}$ & $8.713 \mathrm{t}$ \\
\hline Number of countries & 94 & 259 & 174 \\
\hline R-squared overall & 21 & 21 & 15 \\
R-squared within & 0.07 & 0.14 & 0.11 \\
R-squared between & 0.26 & 0.18 & 0.02 \\
\hline
\end{tabular}

Note: Robust standard errors clustered by country; *** $p<0.001, * * p<0.01, * p<0.05, t p<0.1$. Results from column 1 are similar if Tobit is used instead of OLS. Note that using 5 years period average instead of 10 years period average and lagging the share of elderly does not change results from column 1. Results from column 2 hold if we include orthodoxy of conservative parties as an independent variable. See section 3.2 in appendix for more details on variables and robustness checks.

When using yearly data instead of 10 years period averages, the results are no longer significant for party average but differ for distinct parties. If conservative parties already represent the views of elderly voters regardless of the size of the group, there should be no association between the share of elderly and the economic orthodoxy of conservative party manifestos. This is precisely what I find ${ }^{19}$. By contrast, the share of elderly has a positive significant effect on the economic orthodoxy of social democratic party manifestos as shown in

\footnotetext{
${ }_{18}$ The results hold when using Tobit instead of OLS regression, when using 5 years period average and lagging the share of elderly - see appendix Table A25.

${ }^{19}$ See Table A25 in appendix.
} 
column $2^{20}$. Using the same model, I now interact the share of elderly with the economic orthodoxy of conservative parties as an independent variable ${ }^{21}$ and plot the interacted effect in figure 1: this shows that social democratic parties only respond to an increase in the economic orthodoxy of conservative parties in countries with a large elderly population. Column 3 confirms that the gap in economic orthodoxy between conservative and social democratic parties is negatively associated with the share of the elderly. Overall, these findings are consistent with the claim that social democratic parties have become more economically orthodox to compete for elderly votes.

Figure 1: Effect of conservative party economic orthodoxy on social democratic party economic orthodoxy at different levels of share of elderly

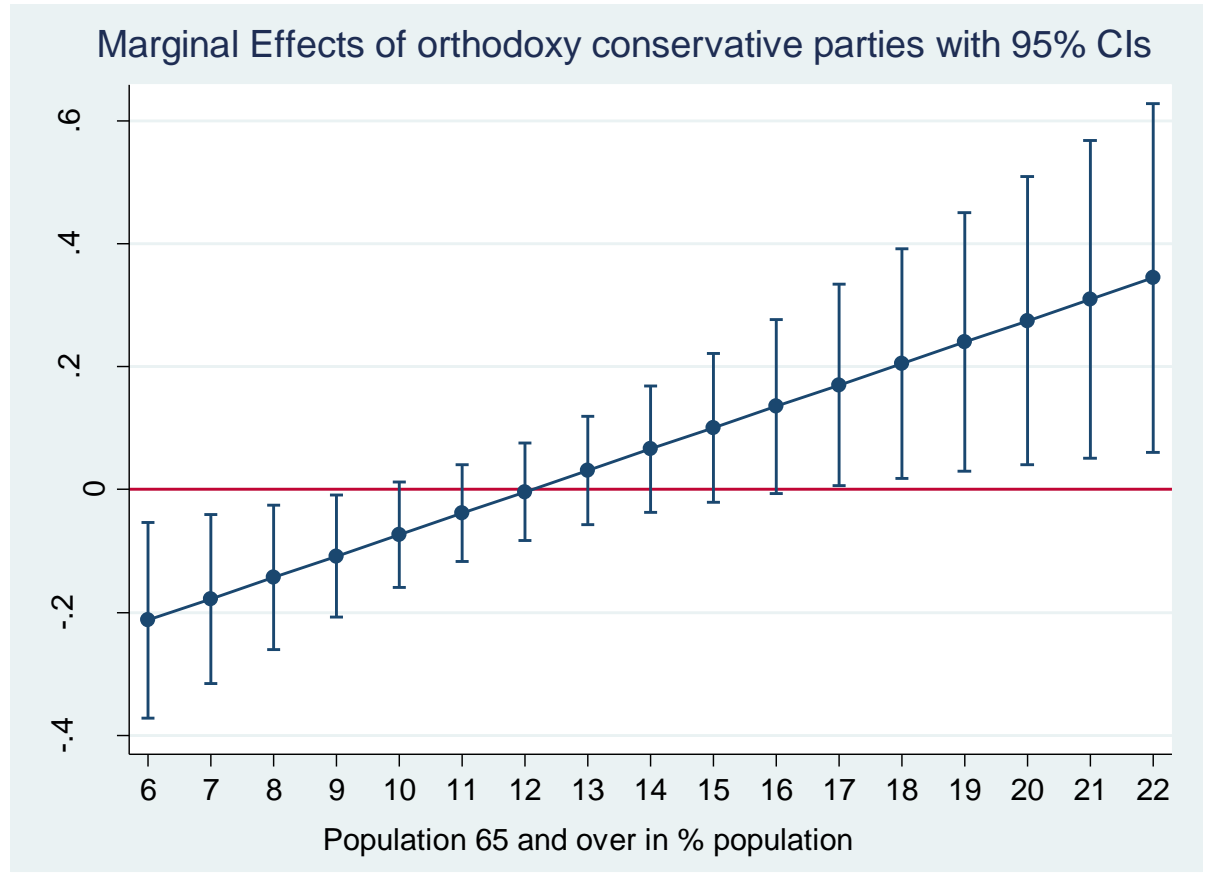

Note: calculated using results from column 2 in table 2 when including in addition an interaction term between the orthodoxy of conservative parties and the share of elderly (country and time effects included).

${ }^{20}$ The results for conservative and social democratic parties are the same when using 5 years period average.

${ }^{21}$ See Table A35 in appendix. 


\subsection{Ageing, economic voting and inflation}

While the previous section shows that parties compete in terms of programs to attract elderly votes by becoming more economically orthodox, it says nothing about the incentives of political parties to contain inflation once in power and why having a large share of elderly might have an effect on these incentives. To test whether the elderly punish the incumbent more than nonelderly/non-retired individuals I use individual level voting data from the second, third and fourth waves of the Comparative Study of Electoral Systems ${ }^{22}$. This covers elections in a range of parliamentary democracies between 2001 and 2016. For each election of the lower house in all elections taking place in these countries during this time period, my dependent variable is coded 1 if the respondent voted for an incumbent party at the last election and 0 otherwise. I control for gender, income, education, being unemployed and being elderly, as well as national inflation and unemployment rates. The latter two variables are a weighted average of the election and preelection years in inflation and unemployment rates, respectively.

Table 3 presents the results. In column 1, the results from a logistic regression analysis suggest that being a retired respondent increases the likelihood of voting for the incumbent, while gender has no effect and being unemployed has a negative effect. Higher inflation and higher unemployment both reduce the likelihood of an individual voting for the incumbent, in line with previous economic voting literature. Having voted for the current incumbent in a previous election increases the chances of voting for that incumbent in the current election. In column 2, I interact inflation with the dummy variable 'retired' and plot the interaction in figure 2: consistent with my expectation, this reveals that an increase in inflation reduces the

${ }^{22}$ This dataset comes from a much wider and ongoing research project on economic voting and social groups with Dr Abel Bojar. 
probability of voting for the incumbent party much more for retired than for non-retired respondents. Note that replacing the retired dummy with an elderly dummy does not change the results ${ }^{23}$.

Table 3: The impact of being elderly and inflation on support for the incumbent

\begin{tabular}{lcc}
\hline Column & $(\mathbf{1})$ & $(\mathbf{2})$ \\
Dependent variable & Vote for incumbent & Lote for incumbent \\
\hline Regression method & $0.169^{* * *}$ & Logit \\
\hline Retired respondent & $(0.022)$ & $0.289^{* * *}$ \\
& $-0.038^{* * *}$ & $(0.031)$ \\
Inflation rate & $(0.004)$ & $-0.026^{* * *}$ \\
& & $(0.004)$ \\
Retired*Inflation & & $-0.046^{* * *}$ \\
& 0.010 & $(0.009)$ \\
\hline Male respondent & $(0.017)$ & 0.010 \\
& $-0.185^{* * *}$ & $(0.017)$ \\
Unemployed respondent & $(0.045)$ & $-0.187^{* * *}$ \\
& $-0.084^{* * *}$ & $(0.045)$ \\
Unemployment rate & $(0.003)$ & $-0.084^{* * *}$ \\
& $2.553^{* * *}$ & $(0.003)$ \\
Past vote for incumbent & $(0.018)$ & $2.552^{* * *}$ \\
& $-1.673^{* * *}$ & $(0.018)$ \\
\hline Constant & $(0.131)$ & $-1.694^{* * *}$ \\
& 88,077 & $(0.131)$ \\
Observations & 0.25 & 88,077 \\
Pseudo R-squared & 0.25 \\
\hline Note: Standard errors in parentheses. $* * * p<0.001, * * p<0.01, * p<0.05$, t $p<0.1$. Education and income \\
controls included but not shown. The results are the same if being an elderly respondent (i.e. aged 65 \\
years old and older) is used instead of being retired.
\end{tabular}

${ }^{23}$ See appendix Table A42. 


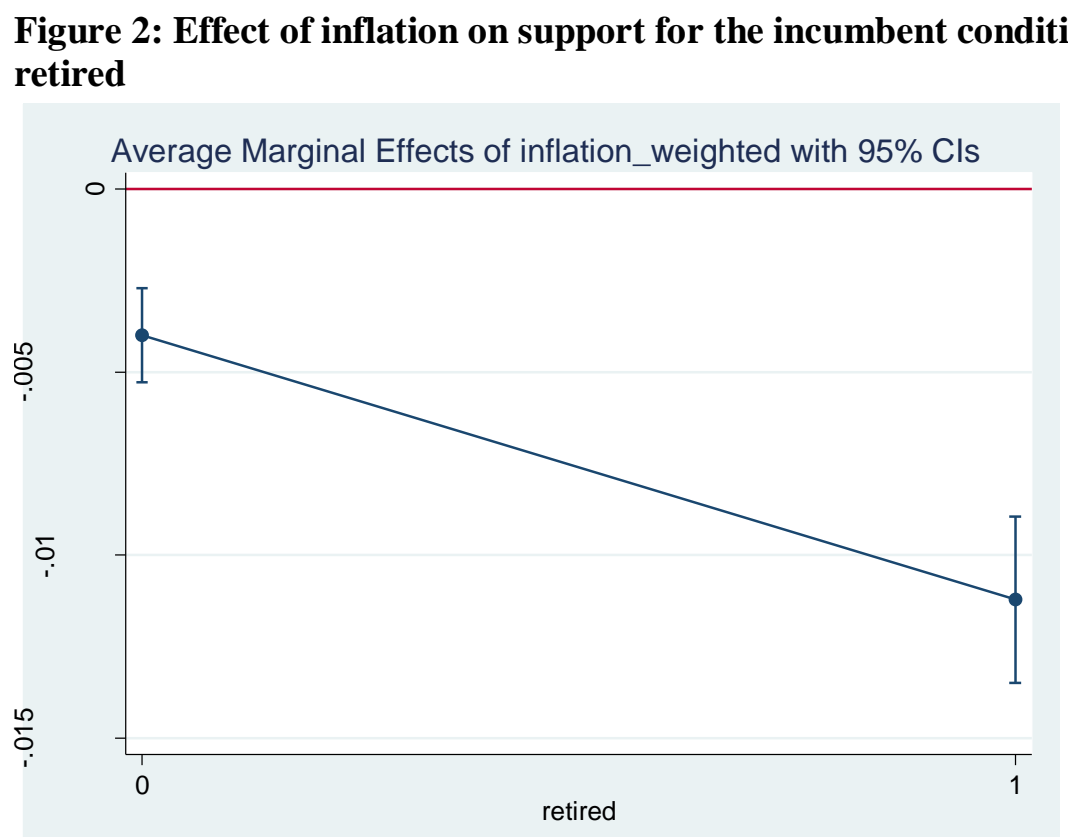

Note: Calculated using results from column 2 in table 3.

\subsection{Ageing and central bank independence}

To test the impact of the share of elderly on the choice of institutions that affect inflation, I collect data for 21 OECD countries in the period 1960 to 2000 on the share of elderly and central bank independence (CBI), as well as a battery of controls. CBI has been shown to be introduced to lower inflation and indeed is associated with lower inflation. Many CBI indices exist (Alesina, Mirrlees, \& Neumann 1989; Cukierman, Webb, \& Neyapti 1992; Eijffinger \& de Haan, 1996; Grilli, Masciandaro, \& Tabellini 1991), but I choose to use the Cuckierman index (Cuckierman, Webb \& Neyapti, 1992) partly because it is widely used and partly because the update by Polillo and Guillén (2005) has the best coverage for my time period. Note however that this index does not capture the ECB's monetary stance and therefore limits my sample to pre-EMU times ${ }^{24}$. I

\footnotetext{
24 This is perhaps for the better since the ECB's policy may have different effects in distinct countries and some authors have argued that unlike national central banks the ECB no longer represents a credible threat to excessive wage agreements. See Hancké (2013) and Johnston (2012). See footnote 24.
} 
control for real GDP growth, unemployment, deficit, trade openness, industrial employment, left cabinet share, union density, wage coordination and social transfers. I also include country and time effects but note that dropping these or running more parsimonious models do not change the results.

Table 4: Determinants of central bank independence

\begin{tabular}{|c|c|c|c|}
\hline $\begin{array}{l}\text { Column } \\
\text { Dependent variable }\end{array}$ & $\begin{array}{l}(1) \\
C B I\end{array}$ & $\begin{array}{l}(2) \\
C B I\end{array}$ & $\begin{array}{l}(3) \\
C B I\end{array}$ \\
\hline Period & Yearly & 5 years average & 10 years average \\
\hline Regression method & $O L S$ & $O L S$ & $O L S$ \\
\hline Share of elderly & $\begin{array}{r}0.045 * * \\
(0.015)\end{array}$ & $\begin{array}{l}0.048^{* * *} \\
(0.015)\end{array}$ & $\begin{array}{l}0.042^{*} \\
(0.016)\end{array}$ \\
\hline Real GDP growth & $\begin{array}{l}-0.003 \\
(0.002)\end{array}$ & $\begin{array}{l}-0.007 \\
(0.007)\end{array}$ & $\begin{array}{l}-0.013 \\
(0.014)\end{array}$ \\
\hline Unemployment rate & $\begin{array}{l}0.013^{*} \\
(0.005)\end{array}$ & $\begin{array}{l}0.012^{*} \\
(0.005)\end{array}$ & $\begin{array}{l}0.011 \\
(0.007)\end{array}$ \\
\hline Deficit & $\begin{array}{c}0.005 \\
(0.004)\end{array}$ & $\begin{array}{c}0.005 \\
(0.007)\end{array}$ & $\begin{array}{c}0.005 \\
(0.010)\end{array}$ \\
\hline Trade openness & $\begin{array}{c}0.002 \mathrm{t} \\
(0.001)\end{array}$ & $\begin{array}{l}0.004^{*} \\
(0.002)\end{array}$ & $\begin{array}{c}0.006 * * \\
(0.002)\end{array}$ \\
\hline Industrial employment & $\begin{array}{l}-0.199 \\
(0.444)\end{array}$ & $\begin{array}{l}-0.637 \\
(0.483)\end{array}$ & $\begin{array}{l}-0.621 \\
(0.713)\end{array}$ \\
\hline Left cabinet share & $\begin{array}{l}-0.000 \\
(0.000)\end{array}$ & $\begin{array}{c}0.000 \\
(0.000)\end{array}$ & $\begin{array}{c}0.001 \\
(0.001)\end{array}$ \\
\hline Union density & $\begin{array}{c}0.001 \\
(0.001)\end{array}$ & $\begin{array}{c}0.002 \\
(0.001)\end{array}$ & $\begin{array}{l}0.003 \\
(0.001)\end{array}$ \\
\hline Wage coordination & $\begin{array}{c}0.012 \\
(0.010)\end{array}$ & $\begin{array}{c}0.021 \\
(0.022)\end{array}$ & $\begin{array}{c}0.016 \\
(0.037)\end{array}$ \\
\hline Social transfers & $\begin{array}{l}-0.011 \mathrm{t} \\
(0.006)\end{array}$ & $\begin{array}{l}-0.015^{*} \\
(0.007)\end{array}$ & $\begin{array}{l}-0.015 \\
(0.008)\end{array}$ \\
\hline Constant & $\begin{array}{l}-0.096 \\
(0.233)\end{array}$ & $\begin{array}{l}-0.058 \\
(0.214)\end{array}$ & $\begin{array}{l}-0.070 \\
(0.266)\end{array}$ \\
\hline Observations & 699 & 162 & 94 \\
\hline Number of countries & 21 & 21 & 21 \\
\hline Country fixed effects & Yes & Yes & Yes \\
\hline Time Effects & Yes & Yes & Yes \\
\hline R-squared overall model & 0.11 & 0.11 & 0.14 \\
\hline R-squared within model & 0.58 & 0.70 & 0.73 \\
\hline R-squared between model & 0.00 & 0.00 & 0.00 \\
\hline
\end{tabular}

Note: Robust standard errors clustered by country in parentheses; *** $p<0.001$, ** $p<0.01, * p<0.05$. See section 3.4 in appendix for more details on variables and robustness checks. 
Table 4 shows the results and report robust standard errors clustered by country. In column 1, I run the regression on yearly data: the share of elderly and unemployment both have positive and significant coefficients at the $5 \%$ level, while trade openness has a positive association and social transfers a negative association at the $10 \%$ level. In column 2 , I run the regression on 5 years period average: the coefficients for the share of elderly and unemployment are still positive and significant, while trade openness and social transfers become significant at the $5 \%$ level. In column 3 , I run the regression on 10 years period average: the result for the share of elderly is unchanged. Overall, the results concerning the preferences of the elderly and the empirical mechanisms linking the share of the elderly to inflation are consistent with my expectations.

\section{Empirical Tests of the Determinants of Inflation}

To test the impact of the share of elderly on inflation rates, I collect annual data for 21 OECD countries in the period between 1960 and $2000^{25}$. This time period allows me to test the determinants of cross-national variation in inflation both in the relatively low inflation period of post-war Europe, the high inflation episodes of the 1970s and the -very - low inflation thereafter. I initially focus on developed economies because they have more established democracies, more comparable economic structures and development levels, and then extend my analysis to a

\footnotetext{
${ }^{25}$ See section 4 in the appendix for countries included and more information on all variables. Most of my data is available until 2012, but my index of central bank independence is available only until 2000. Thereafter Eurozone countries share the same currency and monetary policy is carried out by the European Central Bank (ECB). The common monetary policy of the ECB may introduce polarising inflation dynamics. By removing the sanction that national central banks could impose on the sheltered sector, the European monetary union leads to polarisation between sheltered and non-sheltered sectors. Cross-national variation in inflation rates may also be affected by these polarising dynamics since countries without coordinated wage bargaining will experience greater inflationary pressures in the absence of a national central banks that can punish deviations - see Hancké (2013) and Johnston (2012) for more on this.
} 
sample of 175 countries.

My main dependent variable is the change in the overall consumer price inflation from one year to the next, expressed as a percentage, which is most directly relevant for people's purchasing power. My main independent variable is the share of the population that is 65 years old and over. My baseline model controls for various economic, institutional and political factors that are likely to affect inflation and are discussed with the results.

There are two types of problems with Time Series Cross Section (TSCS) data. The first is that the error structure may suffer from heteroscedasticity and/or auto-correlation which would lead to unreliable test statistics when using Ordinary Least Squares (OLS). I report robust standard errors clustered by country throughout to address the panel structure of my data and neutralize the biases that auto-correlation ${ }^{26}$ and heteroskedasticity ${ }^{27}$ would have on standard errors. The second issue concerns the temporal structure of the data. If both my dependent and my key independent variables are heavily trended upwards or downwards - or more formally have non-constant means - then they may be non-stationary and any statistically significant association between them may be spurious. The Im-Pesaran-Shin unit root test for the inflation variable rejects the null hypothesis that all panels contain a unit root and the Fisher panel unit root test similarly rejects the null hypothesis of a unit root at the $5 \%$ level. However, both tests fail to reject the null hypothesis of non-stationarity the share of elderly ${ }^{28}$.

In principle spurious correlations occur when both variables are non-stationary, which is

\footnotetext{
26 The Woolridge test of autocorrelation rejects the null hypothesis that there is no auto-correlation. See Table A63 in appendix.

${ }^{27}$ I reject the null hypothesis of homoscedasticity using the modified wald test for groupwise heteroscedasticity. See Table A64 in appendix.

28 See Tables A52 and A53 in appendix.
} 
not the case here. Nevertheless I run a wide range of tests to ensure that my results are not spurious. First, I start by running a purely cross-sectional model, which removes any bias arising from the temporal dimension (4.1). Second, when running a TSCS on levels of inflation and the share of elderly, I include both time dummies and a trend (4.2). Third, I run a model with both my dependent variable and key independent variable in first difference and they become stationary thereby removing all risks that this association is spurious (4.3). Fourth, I run an error correction model which models the temporal dynamics (4.4). Fifth, I rerun all these models on a world sample and check whether removing the high income countries changes the association (4.5). The association holds throughout and this is not driven by economic development since I include GDP per capita in all my regressions and removing countries with high GDP per capita in the world sample does not change my results.

\subsection{Cross-sectional analysis of inflation}

The bivariate correlation coefficient between inflation and the share of elderly in my sample of 21 OECD countries since 1960 is -0.2797 (significant p-value of 0.000 ). I compute the average for the whole time period for all variables and run a cross-sectional OLS analysis on 21 OECD countries.

Given limited degrees of freedom, I include only essential independent variables. I start by including the share of elderly, GDP growth, the unemployment rate which may put downward pressure on inflation through its effect on wages, and the degree of capital openness since capital may exit countries where inflation is deemed too high $^{29}$. I then add the degree of trade openness which makes inflation more costly, and CBI which can be expected to lead to lower inflation. As

29 See Table A66 in appendix. 
shown in table 5, the model performs well: $82 \%$ of the variation in the dependent variable is explained by the variation in the independent variables. The coefficients for capital and trade openness are negative and significant while unemployment is positive and significant, and CBI is not significant. The share of elderly is negative and statistically significant and the results are robust to the inclusion of additional controls such as left control of cabinet, union density, or deficits, and to the exclusion of outliers (Greece, Portugal, Spain, Germany, and Sweden). Equally, stepwise deletion of insignificant variables does not change the results ${ }^{30}$.

\section{Table 5: Cross-sectional determinants of inflation}

\begin{tabular}{lc}
\hline Dependent variable & Inflation \\
\hline Share of elderly & $-0.23265^{*}$ \\
& $(0.130)$ \\
Capital openness & $-2.31281^{* * *}$ \\
& $(0.389)$ \\
Unemployment rate & $0.13585^{*}$ \\
& $(0.064)$ \\
Real GDP & $-0.46660^{*}$ \\
& $(0.257)$ \\
CBI & 1.73463 \\
& $(1.414)$ \\
Trade openness & $-0.00821^{*}$ \\
& $(0.005)$ \\
\hline Constant & $12.01223^{* * *}$ \\
& $(2.462)$ \\
Observations & 21 \\
R-squared & 0.82 \\
\hline
\end{tabular}

Note: robust standard errors in parentheses; *** $p<0.01, * * p<0.05, * p<0.1$. See sections 4.1 and 4.2 in appendix for more details on variables and robustness checks, respectively.

\subsection{Time-series cross-section analysis}

As I have more degrees of freedom when keeping both the time and cross-sectional dimensions, I can include more controls in the TSCS analysis. In addition to the variables discussed in the

\footnotetext{
30 See Tables A66 to A70 and Figure A67 in appendix.
} 
previous section, I also include the following variables: union density can be expected to lead to higher inflation by increasing the bargaining power of workers or to lower inflation if the olsonian effect dominates; left control of the government should be associated with higher inflation; and wage coordination allows unions to internalize the effects of their wage claims which could otherwise lead to inflation. I choose a wage coordination index which takes values between 1 (low coordination) and 5 (high coordination) (Visser 2013). Inspections for collinearity did not reveal any problems with this wider set of independent variables.

I start with an empty model with just the share of elderly and then stepwise introduce country fixed effects, time effects, and then a trend ${ }^{31}$. The full results are presented in table 6 . The share of elderly is negative and statistically significant: an additional 1 percentage point increase in the share of elderly is associated with 0.648 percentage point fall in inflation rates. The unemployment rate and capital openness are both negative and significant, while left control of the cabinet, wage coordination, and central bank independence are not statistically significant. Union density has a positive and significant association. Crucially I control for GDP per capita which captures the changing level of economic development of countries over time. This is important because it may be that economic modernization results in both higher life expectancy and falling inflation. However, the variable is not statistically significant. Since country and time effects are included, my results are not driven by unobserved heterogeneity. The trend is negative but not statistically significant.

I carry out a battery of robustness checks. Including a lagged dependent variable or lagging all independent variables does not change the results. Using Generalized Least Squares

31 Table A71 in appendix. 
(GLS) or reporting Panel Corrected Standard Errors (PCSE) with an AR(1) process instead of robust clustered standard errors does not change my result concerning the share of elderly.

Dichotomizing the dependent variable to take value 1 if inflation is above 10 (very high

inflation) and 0 otherwise, and running a logistic model does not change the results: the share of elderly continues to be significant at the $10 \%$ level $^{32}$.

Table 6: TSCS determinants of inflation

\begin{tabular}{lc}
\hline Dependent variable & Inflation \\
\hline Share of elderly & $-0.648^{*}$ \\
& $(0.269)$ \\
Unemployment rate & $-0.313^{* *}$ \\
& $(0.109)$ \\
GDP per capita, 1000s & 0.228 \\
& $(0.176)$ \\
Capital Openness & $-0.885^{*}$ \\
& $(0.339)$ \\
Trade openness & -0.032 \\
& $(0.023)$ \\
Union Density & $0.099^{* * *}$ \\
& $(0.023)$ \\
Left parties, \% cabinet posts & 0.001 \\
& $(0.003)$ \\
Wage coordination & 0.078 \\
& $(0.167)$ \\
Central Bank Independence & 1.486 \\
& $(1.122)$ \\
\hline Constant & $10.946^{* *}$ \\
& $(2.893)$ \\
\hline Fixed effects & Yes \\
Time effects & Yes \\
Trend & -0.080 \\
\hline Observations & 597 \\
Number of countries & 21 \\
\hline R-squared within model & 0.77 \\
R-squared overall model & 0.44 \\
\hline Note Robuared between model & 0.01 \\
\hline
\end{tabular}

Note: Robust standard errors clustered by country in parentheses; $* * * p<0.001, * * p<0.01, * p<0.05, t$ $p<0.1$. The dependent variable is inflation rate as captured by Consumer Price Index. See sections 4.1 and 4.3 in appendix for more details on variables and robustness checks, respectively.

${ }^{32}$ See Tables A71 and A72. 
In addition, controlling for a squared term of union density ${ }^{33}$, debt, deficit, terms of trade, educational attainment, industrial employment, social transfers, union authority, union concentration, home ownership, structural unemployment, employment protection legislation, whether the country is in Europe, or whether the country is a Liberal Market Economy does not change the results ${ }^{34}$. I have also rerun my analysis when replacing the share of elderly by the dependency rate ${ }^{35}$ and the results are unchanged. Finally, I carried out a stepwise jackknife country exclusion and the result are robust to the exclusion of any one country ${ }^{36}$.

\subsection{TSCS analysis on first difference in dependent and independent variables}

As noted previously, inflation is stationary but the share of elderly is non-stationary. While my cross-sectional analysis cannot by design be biased by non-stationarity and my earlier TSCS analysis included both time effects and a trend, I now rerun my analysis on the first difference of both inflation and the share of elderly, where both variables are non-stationary ${ }^{37}$ and hence cannot be spuriously related. As before I first run an empty model while controlling for country and time effects as well as including a trend, the coefficient is negative and statistically significant. This association is robust to a jackknife stepwise country exclusion ${ }^{38}$.

Next, I add my independent variables and present the results in table 7. The coefficient for the share of elderly remains negative and statistically significant. The first difference in unemployment is negatively associated whereas the first difference in GDP per capita and wage coordination are not significantly associated. Union density, left wing control of cabinet and

\footnotetext{
33 To capture the Calmfors Driffil (1988) hypothesis.

34 See Tables A73 and A74 in appendix.

35 The dependency rate is the number of elderly divided by working age population - see Table A75 in appendix.

36 See Table A76 in appendix.

37 See Tables A55 and A58 in appendix.

38 See Tables A78 to A80 in appendix.
} 
central bank independence are all included in levels for theoretical reasons ${ }^{39}$ : only union density is statistically significant at the $10 \%$ level.

Table 7: First difference analysis

\begin{tabular}{lc}
\hline Dependent variable & First difference inflation rate \\
\hline Share of elderly & $-1.209 \mathrm{t}$ \\
(first difference) & $(0.634)$ \\
Unemployment rate & $-0.418^{*}$ \\
(first difference) & $(0.170)$ \\
GDP per capita, 1000s & -0.100 \\
(first difference) & $(0.209)$ \\
Wage coordination & 0.112 \\
(first difference) & $(0.125)$ \\
Union Density & $-0.023 \mathrm{t}$ \\
& $(0.012)$ \\
Left-wing parties in \% cabinet posts & 0.000 \\
& $(0.003)$ \\
Central Bank Independence & 0.581 \\
& $0.450)$ \\
\hline Constant & 0.619 \\
Observations & 644 \\
Number of countries & 21 \\
\hline Fixed Effects & Yes \\
Time Effects & Yes \\
Trend & 0.024 \\
\hline R-squared within model & 0.37 \\
R-squared overall model & 0.34 \\
R-squared between model & 0.00
\end{tabular}

Note: Robust standard errors clustered by country in parentheses $* * * p<0.001, * * p<0.01, * p<0.05, t$ $p<0.1$. See sections 4.1 and 4.4 in appendix for more details on variables and robustness checks.

Removing country fixed effects, replacing the share of elderly by the dependency rate, or rerunning the regression with Generalized Least Squares (GLS) or Panel Corrected Standard Errors (PCSE) with an AR(1) process does not change my results ${ }^{40}$. I check the robustness of my results for the same additional controls as in the previous analysis on levels and the effect of the

39 The argument about the inclusiveness and strength of union movements is an argument about the level of union density. Similarly what matters for the left is the level of control rather than increase in percentage of cabinet seats and central bank independence only changes rarely so running it as a first difference would artificially limit its potential effect.

${ }^{40}$ See Table A78 in appendix. 
share of elderly on inflation remains negative and significant ${ }^{41}$. Rerunning a more parsimonious model with just the first differences in the share of elderly, unemployment, GDP per capita and the level of CBI does not change my results. As before, jackknife stepwise country exclusion does not change my results. Careful examination of inflation rate over the whole sample reveals that there are outliers in the 1970s and in the 1990s. I therefore rerun my analysis while excluding the 1970s and then while excluding the 1990s, respectively, from my sample. The coefficient for the share of elderly remains statistically significant ${ }^{42}$. Overall, I conclude that the association between inflation and the share of elderly is not spuriously driven by nonstationarity, omitted variable bias, unobserved country or time heterogeneity nor by problems with the structure of my errors.

\subsection{Dynamics of adjustments: Error Correction Model}

A more formal way of investigating time dynamics is to use an Error Correction Model (ECM). So far my results show that there is a robust association between the share of elderly and inflation, but say little about the dynamics of adjustment. I therefore use a single equation ECM of the standard form ${ }^{43}$. In the first column of table 8 , I report a parsimonious model with the share of elderly as my only independent variable. The results suggest that the short run effect of an increase in elderly on inflation is 0.042 but not statistically significant. This makes sense conceptually since once one clearly distinguishes between long and short run effects, one cannot expect inflation rates to directly and instantaneously respond to a change in the share of the elderly.

\footnotetext{
41 See Tables A81 to A83 in appendix.

${ }^{42}$ See Table A83 in appendix.

43 See section 4.5 in appendix for details on the ECM.
} 
The long run effect is calculated by taking the ratio of the coefficient of the lagged share of elderly to the coefficient of the lagged dependent variable and is equal to -0.79 , with an adjustment process (error correction) of 0.14 per period $^{44}$. In other words, the total long run effect of 1 percentage point increase in the share of elderly is 0.79 percentage point lower inflation, but in $t+1$ this initially results in $0.14 * 0.79$ reduction in inflation, in $t+2$ and so on. Because the estimate of the long run coefficient -0.79 is a recalculation from two estimated coefficients, we need to also recalculate the standard error to assess whether it is statistically significant, which we can do using the Stata command nlcom. As can be seen in the last row before the constant, the long run effect is statistically significant at the 0.001 level. Note that including country fixed effects does not change the results.

Next, I recalculate the long term effect when including one control at a time by itself: controlling for trade openness, capital openness, CBI, GDP per capita, union density, unemployment rate, wage coordination, social transfers, left governments, deficit, home ownership or employment protection legislation does not change the results ${ }^{45}$. I then stepwise add the following variables in both lagged and first difference (to calculate their short and long term effects) and then rerun the regression with each new additional variable: GDP per capita, CBI, capital openness, employment protection legislation, union density, unemployment rate, wage coordination, social transfers, left share of cabinet, and deficit. For each regression I calculate and report the long term effect of the share of elderly which remains negative and significant ${ }^{46}$. Note that as more independent variables are included the size of the sample is

\footnotetext{
${ }^{44}$ See section 4.5 in appendix for the proof of how the long run effect and error correction can be derived from this empirical model.

${ }^{45}$ See Table A90 in appendix.

${ }^{46}$ See Tables A91 and A92 in appendix.
} 
reduced since data availability is not consistent across variables. In column 2 , I report the final model which includes country and time effects as well as a trend: the long term effect of the share of elderly on inflation remains negative and statistically significant ${ }^{47}$.

Table 8: Results from an Error Correction Model

\begin{tabular}{|c|c|c|}
\hline \multirow{2}{*}{$\begin{array}{l}\text { Column } \\
\text { Dependent variable }\end{array}$} & (1) & $(2)$ \\
\hline & \multicolumn{2}{|c|}{ First difference in inflation } \\
\hline $\begin{array}{l}\text { Inflation (lagged) } \\
\text { (lage }\end{array}$ & $-0.140 * * *$ & $-0.459 * * *$ \\
\hline Share of elderly (first difference) & -0.042 & -1.095 \\
\hline Share of elderly (lagged) & $-0.111 * * *$ & $-0.228 \mathrm{t}$ \\
\hline GDP per capita (first difference) & & $-1.048 * *$ \\
\hline GDP per capita (lagged) & & $0.446 * *$ \\
\hline CBI (first difference) & & 2.512 \\
\hline CBI (lagged) & & 1.165 \\
\hline Capital openness (first difference) & & -0.482 \\
\hline Capital openness (lagged) & & $-0.444 * *$ \\
\hline Employment in industry (first difference) & & -8.318 \\
\hline Employment in industry (lagged) & & 5.856 \\
\hline Union Density (first difference) & & $0.068 \mathrm{t}$ \\
\hline Union Density (lagged) & & 0.023 \\
\hline Unemployment rate (first difference) & & -0.137 \\
\hline Unemployment rate (lagged) & & -0.101 \\
\hline Coordination (first difference) & & 0.089 \\
\hline Coordination (lagged) & & 0.057 \\
\hline Social Transfers (first difference) & & $-0.382 *$ \\
\hline Social Transfers (lagged) & & -0.137 \\
\hline Left share of cabinet seats (first difference) & & -0.001 \\
\hline Left share of cabinet seats (lagged) & & -0.001 \\
\hline Deficit (first difference) & & $0.154 * *$ \\
\hline Deficit (lagged) & & -0.065 \\
\hline Long run effect of elderly on inflation: & $-0.7949738 * * *$ & $-0.4961375^{*}$ \\
\hline Constant & $2.184 * * *$ & $6.340 * *$ \\
\hline Observations & 1,089 & 558 \\
\hline Number of countries & 21 & 21 \\
\hline R-squared within model & 0.10 & 0.59 \\
\hline R-squared overall model & 0.08 & 0.31 \\
\hline R-squared between model & 0.01 & 0.61 \\
\hline
\end{tabular}

Note: Robust standard errors clustered by country; $* * * p<0.001, * * p<0.01, * p<0.05, t p<0.1$. The coefficient for the short term effect of a change in the share of elderly and of the lagged inflation capturing the adjustment process (or error correction) can be interpreted as such, but interpreting the long run effect requires recalculating the coefficient (and its associated standard error) directly using the Stata nlcom command (this is reported in the row "Long run effect of elderly on inflation"). See section 4.5 in appendix for more details on ECMs and for a range of robustness checks.

${ }^{47}$ The short term and recalculated long term effects of each independent variable are reported in table A92 in the appendix. 


\subsection{Ruling out economic modernization and an 'economic' channel with a world sample}

It would in principle be possible that OECD countries have developed economically in a way that has jointly led to ageing and lower inflation. As economies modernize, the birth rate falls and longevity increases at the same time as economic institutions become more effective at containing inflation. However, this alternative 'economic modernization' narrative of ageing and falling inflation is unlikely to bias my results because I control for GDP per capita which captures economic modernization throughout my empirical analysis in previous sections. At the same time, because OECD countries are broadly at a similar level of economic development as well as having aged significantly, it might be difficult to arbitrate between my argument and this alternative modernization narrative. Therefore I now extend my analysis to include countries with many different levels of economic development, share of elderly and inflation rates by collecting data on a much larger sample including 175 countries between 1960 and $2013^{48}$. This also allows me to investigate whether my argument 'travels' to developing and emerging economies.

I first start by calculating period average for all variables that are available for a large number of countries. I run a series of cross-sectional regressions with just the share of elderly on the right hand side and then add stepwise GDP growth, unemployment, a democratic index, stock market capitalization, and left control of the executive ${ }^{49}$. The coefficient for the share of elderly is negative and significant, while the size of stock market is negatively associated with inflation ${ }^{50}$. Controlling for national income per capita does not change the results. Including an

\footnotetext{
${ }^{48}$ Depending on model specification, the number of countries and years that are covered by my analysis varies as a result of differences in the data availability of each independent variable.

${ }^{49}$ See section 4.6 in appendix for variable source and description, and all results discussed in this section.

${ }^{50}$ Consistent with Posen's argument.
} 
index of central bank independence that is available for 93 countries in 2003 and running a crosssectional analysis does not change my results concerning the impact of the elderly ${ }^{51}$.

Next, I run a TSCS regression analysis on the yearly data while including both time and country effects. Some countries have very high inflation which might be driving results so I impose several restrictions on the dependent variable ( $<100,<50$ and logarithmic transformation) which does not change the results. Rerunning the analysis in first differences while controlling for GDP growth or national income per capita does not change the results. I then rerun this analysis on GDP growth and the share of elderly in both lags and first differences, while including time and country effects, to be able to calculate long run effects. As was the case in the sample of OECD countries, the long run effect of the share of elderly is negative and significant ${ }^{52}$. I then return to my analysis in levels and add stepwise unemployment, stock market size, a democracy index, and Left executive. Replacing GDP growth by national income per capita does not change the results ${ }^{53}$.

I noted earlier that the relationship between inflation and the share of the elderly could occur through an economic rather than political mechanisms. Given my earlier evidence on the political mechanisms, it is clear that there is at least part of the effect which occurs through the political arena, but this does not rule out an additional non-electoral economic mechanism. One way to explore this issue further is to compare the effect of the elderly on inflation rates in countries with different degrees of democracy, using an additive index of the degree of democracy that takes values 0 to 10 (higher values suggest more democratic institutions).

${ }^{51}$ See appendix Table A96.

${ }^{52}$ See Table A98 in appendix.

${ }^{53}$ See Table A99 in appendix. 
Figure 3: Effect of share of elderly on inflation depending on degree of democracy

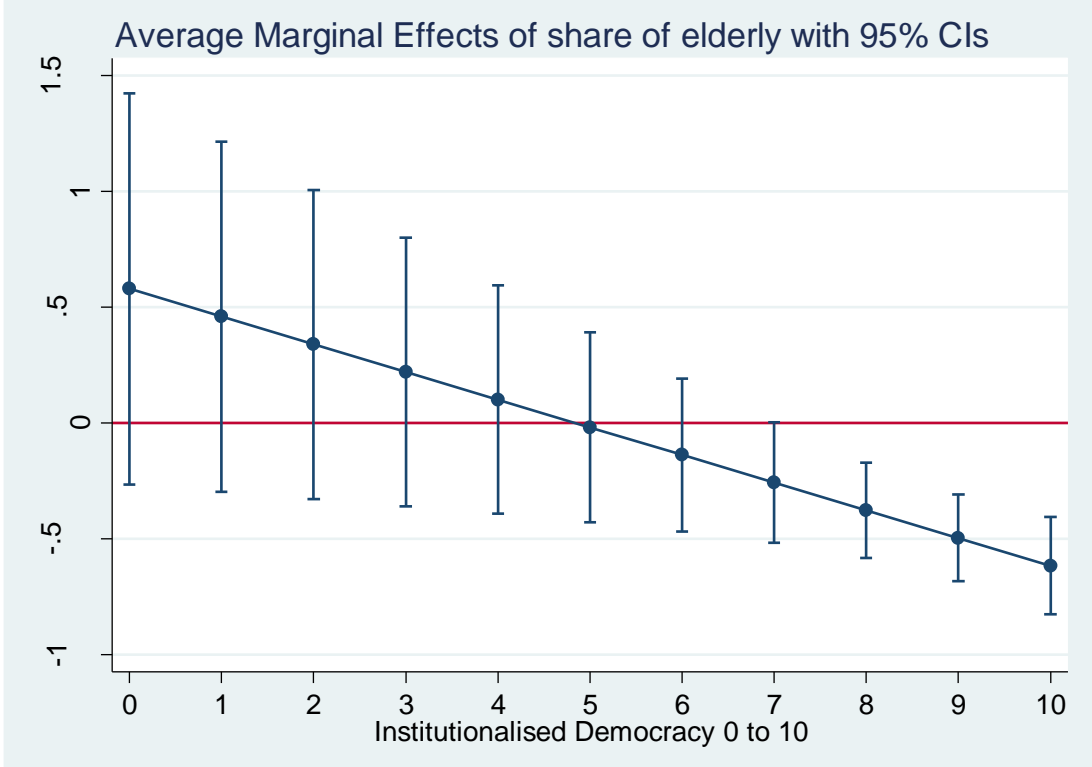

Note: this graph plots the interaction effect between the share of elderly and the index of democracy in a regression that controls for GDP growth and time dummies and where all observations with a dependent variable with values higher than 100 are excluded from analysis. The confidence interval use robust standard errors clustered by country. Note that including country effects, replacing GDP growth by national income per capita, or excluding all countries with national income per capita above $\$ 20,000$ does not change the results (see section 4.6 in appendix).

I rerun a simple model of inflation as a function of GDP growth, time dummies and an interaction between the share of elderly and the democratic index, and present the interaction in Figure 3: the share of elderly is only negatively and significantly associated with inflation when countries have a democratic score of 8,9 or 10 (i.e. when they have 'high' democracy scores). If the causal mechanism operated mainly through a non-electoral channel, the effect would be statistically significant regardless of the degree of democracy. This interaction is unchanged if we include country fixed effects, or we control for unemployment or stock market size ${ }^{54}$. If we include national income per capita, which neutralizes the effect of economic modernization, we

54 See Figures A101 to A103 in appendix. 
observe that the negative effect of the share of elderly on inflation only holds in countries with a democratic score of 9 or $10^{55}$. Finally, we can exclude all countries that are economically modernized by restricting the sample to countries with national income per capita under $\$ 20,000^{56}$. The results are unchanged so the association between inflation and ageing does not occur through an economic mechanism nor is it biased by broader economic modernization dynamics.

\section{Conclusion}

Previous literature on the determinants of inflation emphasizes the role of ideas and institutions, and to a lesser extent interest group. While these approaches are valuable, this article has argued that by neglecting the role of electoral politics, these explanations miss out an important determinant of the cross-national variation in inflation rates. For both methodological and theoretical reasons, this article has focused on the share of elderly to show how aging affects inflation rates through electoral politics.

I have argued that countries with a larger share of elderly exhibit lower inflation because elderly voters are inflation averse, numerous, and politically powerful. Political parties therefore compete for their votes before elections and are influenced by their preferences while in government because they fear electoral penalties at the next section. As a result, in countries with a larger share of elderly, governments pursue lower inflation.

A wide range of findings support this argument: Older voters are more inflation averse,

${ }^{55}$ See Figure A102 in appendix.

${ }^{56}$ See Figure A104 in appendix. 
countries with more elderly have more economically orthodox political parties, the electoral punishment for inflation is higher among elderly voters, and countries with more elderly exhibit higher CBI and lower inflation. I have tested the latter association between the share of elderly and inflation rates using a wide variety of specifications, methods, and samples. My results show that the magnitude of this effect is sufficiently strong to suggest we were missing an important determinant of inflation rates, and the evidence does not suggest that non-stationarity, omitted variable bias, unobserved heterogeneity, or economic modernization are biasing this association.

Although this article has focused on the effect of only one social group — the elderly — on one main economic outcome-inflation - this represents an important contribution to the comparative political economy literature in several ways. First, my findings show convincingly that electoral politics, not just institutions or ideas, also matter for explaining variation in inflation rates. Further research should analyse the impact of other electoral groups on inflation. Second, extending my argument beyond the case of inflation would suggest that aging may have important effects on other economic outcomes and policies. This represents a valuable avenue for further research. Third, ageing may have represented a powerful driver behind the shift to a low inflation regime in the past decades, though it is unlikely to alone explain such a shift. Looking to the future, as populations continue to age, the political imperative to keep inflation low may force politicians to adopt suboptimal economic policies 


\section{References}

Alesina, A., Mirrlees, J., \& Neumann, M. (1989). Politics and Business Cycles in Industrial Democracies. Economic Policy, 4(8), 55.

Alesina, A., Roubini, N., \& Cohen, G. (1999). Political cycles and the Macroeconomy. Cambridge, Mass.: MIT.

Alt, J. \& Crystal, K. (1983). Political economics. Brighton: Wheatsheaf Books.

Ansell, B. (2014). The Political Economy of Ownership: Housing Markets and the Welfare State. American Political Science Review, 108(02), 383-402.

Antolin, P. (2009) Private Pensions and the Financial Crisis: How to Ensure Adequate Retirement Income from DC Pension Plans. OECD report, Paris. Accessed at:

http://www.oecd.org/daf/fin/44628862.pdf

Bach, G. \& Stephenson, J. (1974). Inflation and the Redistribution of Wealth. The Review Of Economics And Statistics, 56(1), 1-13.

Barro, R. \& Gordon, D. (1983). A Positive Theory of Monetary Policy in a Natural Rate Model. Journal Of Political Economy, 91(4), 589-610.

Berger, H., de Haan, J., \& Eijffinger, S. (2001). Central Bank Independence: An Update of Theory and Evidence. Journal Of Economic Surveys, 15(1), 3-40.

Boix, C. (1998). Political parties, growth and equality. Cambridge, U.K: Cambridge University Press.

Briault, C. (1995). The Costs of Inflation. Bank of England Quarterly Bulletin, 33-45.

Brooks, C. \& Manza, J. (2006). Social Policy Responsiveness in Developed Democracies. American Sociological Review, 71(3), 474-494.

Browning, E. (1975). Why the Social Insurance Budget is Too Large in a Democracy. Economic Inquiry, 13(3), 373-388.

Bullard J., Garriga C., \& Walker C. J. (2012). Demographics, Redistribution, and Optimal Inflation. Federal Reserve Bank of St. Louis Review, 94, 419-39.

Busemeyer M.-R., Goerres, A., \& Weschle, S. (2008). Demands for Redistributive Policies in an Era of Demographic Aging: The Rival Pressures from Age and Class in 15 OECD Countries (MPIfG Discussion Paper 08/3). Köln: Max-Planck-Institut für Gesellschaftsforschung.

Butler, D., \& Stokes, D. (1983). Political change in Britain. London: MacMillan Press.

Calmfors, L. \& Driffill, J. (1988). Bargaining Structure, Corporatism and Macroeconomic Performance. Economic Policy, 3(6), 14-61.

Cameron, D. (1984). Social Democracy, Corporatism, Labor Quiescence, and the Representation of Economic Interest in Advanced Capitalist Society. In J. Goldthorpe (Ed.), Order and Conflict in Contemporary Capitalism. New York: Oxford University Press. 
Canes-Wrone, B. (2015). From Mass Preferences to Policy. Annual Review Of Political Science, 18(1), 147-165.

Conesa, J., \& Krueger, D. (1999). Social Security Reform with Heterogeneous Agents. Review Of Economic Dynamics, 2(4), 757-795.

Cooley, T., \& Soares, J. (1999). A Positive Theory of Social Security Based on Reputation. Journal Of Political Economy, 107(1), 135-160.

Cukierman, A., Web, S., \& Neyapti, B. (1992). Measuring the Independence of Central Banks and Its Effect on Policy Outcomes. The World Bank Economic Review, 6(3), 353-398.

de Mello, L., Schotte, S., Tiongson, E., \& Winkler, H. (2016). Greying the Budget: Ageing and Preferences over Public Policies. Kyklos, 70(1), 70-96.

Debelle, G., \& Fischer, S. (1994). How Independent Should a Central Bank Be?. In Conference on Monetary Policy in a Low Inflation Regime. North Falmouth, Massachusetts.

Eichengreen, B. (1996). Institutions and Economic Growth: Europe Since World War II. In N. Crafts \& G. Toniolo (Eds.), Economic Growth in Europe Since 1945 (pp. 38-72). Cambridge: Cambridge University Press.

Eijffinger, S., \& de Haan, J. (1996). The Political Economy of central-Bank Independence, Special Papers in International Economics, No. 19, Princeton University.

Erikson, R., MacKuen, M., \& Stimson, J. (2000). Bankers or peasants revisited: economic expectations and presidential approval. Electoral Studies, 19(2-3), 295-312.

Erikson, R., MacKuen, M., \& Stimson, J. (2002). The macro polity. New York: Cambridge University Press.

Esping-Andersen, G., \& Sarasa, S. (2002). The generational conflict reconsidered. Journal Of European Social Policy, 12(1), 5-21.

European Commission. (2014). The 2015 Ageing Report Underlying Assumptions and Projection Methodologies. Brussels: European Commission

Fair, R. C., \& Dominguez K. (1991). Effects of the changing U.S. age distribution on macroeconomic equations. American Economic Review, 81, 1276-1294.

File, T. (2013). Young-Adult Voting: An Analysis of Presidential Elections, 1964-2012. Current Population Survey Reports. Washington, DC: U.S. Census Bureau. 20-572

Fletcher, D., \& Kenny, L. (2008). The Influence of the Elderly on School Spending in a Median Voter Framework. Education Finance And Policy, 3(3), 283-315.

Franzese, R. (2003). Multiple Hands on the Wheel: Empirically Modeling Partial Delegation and Shared Policy Control in the Open and Institutionalized Economy. Political Analysis, 11(04), 445-474.

Friedman, M. (1968). The role of monetary policy. American Economic Review, 58, 1-17. 
Galasso, V. (2006). The Political Future of Social Security in Ageing Societies. Cambridge, USA: MIT Press.

Galasso, V., \& Profeta, P. (2007). How does ageing affect the welfare state?. European Journal Of Political Economy, 23(2), 554-563.

Goerres, A. (2007). Why are Older People More Likely to Vote? The Impact of Ageing on Electoral Turnout in Europe. The British Journal Of Politics And International Relations, 9(1), 90-121.

Goerres, A. (2008). The grey vote: Determinants of older voters' party choice in Britain and West Germany. Electoral Studies, 27(2), 285-304.

Goerres, A. (2009). The political participation of older people in Europe. Houndmills, Basingstoke, Hampshire: Palgrave Macmillan.

Grilli, V., Masciandaro, D., Tabellini, G., Malinvaud, E., \& Pagano, M. (1991). Political and Monetary Institutions and Public Financial Policies in the Industrial Countries. Economic Policy, 6(13), 341-392.

Hall, P. \& Franzese, R. (1998). Mixed Signals: Central Bank Independence, Coordinated Wage Bargaining, and European Monetary Union. International Organization, 52(03), 505-535.

Hall, P. (1986). Governing the economy: The Politics of State Intervention in Britain and France. Cambridge: Polity.

Hancké, B. (2013). Unions, central banks and EMU: labour market institutions and monetary integration in Europe. Oxford: Oxford University Press.

Harris, A., Evans, W., \& Schwab, R. (2001). Education spending in an aging America. Journal Of Public Economics, 81(3), 449-472.

Hayo, B. (1998). Inflation culture, central bank independence and price stability. European Journal Of Political Economy, 14(2), 241-263.

Hibbs, D. (1977). Political Parties and Macroeconomic Policy. American Political Science Review, 71(04), 1467-1487.

Hibbs, D. (1979). The Mass Public and Macroeconomic Performance: The Dynamics of Public Opinion Toward Unemployment and Inflation. American Journal Of Political Science, 23(4), 705-731.

Hibbs, D. A. Jr. (1986). Political parties and macroeconomic policies and outcomes in the United States. The American Economic Review, 76, 66-70.

Hollibaugh, G., Rothenberg, L., \& Rulison, K. (2013). Does It Really Hurt to Be Out of Step?. Political Research Quarterly, 66(4), 856-867.

IMF. (2004). World Economic Outlook. Washington DC: International Monetary Fund.

Iversen, T. (1999). Contested economic institutions. New York: Cambridge University Press.

Iversen, T., \& Soskice, D. (2006). New Macroeconomics and Political Science. Annual Review Of Political Science, 9(1), 425-453. 
Johnston, A. (2012). European Economic and Monetary Union's perverse effects on sectoral wage inflation: Negative feedback effects from institutional change?. European Union Politics, 13(3), 345-366.

Kitschelt, H. (2004). Diversification and reconfiguration of party systems in postindustrial democracies. Bonn: Internat. Politikanalyse, Friedrich-Ebert-Stiftung.

Kuttner, K., \& Posen, A. (2009, January). Central Bank Independence: Conservative, yes, but causal? Paper presented at the ASSA Annual Meeting, San Francisco.

Laidler, D., (Ed.). (1997). Where we go from here: inflation targets in Canada's Monetary Policy Regime. Toronto, CD: Howe Institute.

Lange, P., \& Garrett, G. (1985). The Politics of Growth: Strategic Interaction and Economic Performance in the Advanced Industrial Democracies, 1974-1980. The Journal Of Politics, 47(3), 792-827.

Lelyveld, I. (1999). Inflation or unemployment? Who cares?. European Journal Of Political Economy, 15(3), 463-484.

Lewis-Beck, M. (1988). Economics and Elections: The Major Western Democracies. Ann Arbor: The University of Michigan Press.

Lewis-Beck, M. S., \& Stegmaier M. (2007). "Economic Models of Voting.” In R. Dalton \& H-D. Klingemann (Eds.), The Oxford Handbook of Political Behavior (pp. 518-537). Oxford: Oxford University Press, 2007.

Lewis-Beck, M., \& Stegmaier, M. (2000). Economic Determinants of Electoral Outcomes. Annual Review Of Political Science, 3(1), 183-219.

Lindh, T. \& Malmberg, B. (2000). Can age structure forecast inflation trends?. Journal Of Economics And Business, 52(1-2), 31-49.

Lynch J. (2006). Pension Inequality and Pension Policy Preferences in Europe: Self-Interest, Policy Feedbacks, or None of the Above?. (Working Paper). New York: Council for European Studies Working Paper.

Lynch, J. \& Myrskylä, M. (2009). Always the third rail? pension income and policy preferences in European democracies. Comparative Political Studies, 42(8), 1068-1097.

MacManus, S. (2000). Targeting Senior Voters: Campaign Outreach to Elders and Others with Special Needs. Lanham, Md: Rowman and Littlefield Publishers.

Maxfield, S. (1997). Gatekeepers of growth: the international political economy of central banking in developing countries. Princeton: Princeton University Press.

McNamara, K. (1999). The currency of ideas. Ithaca, N.Y.: Cornell University Press.

McRae, C. (1977). A Political Model of the Business Cycle. Journal Of Political Economy, 85(2), 239263.

Miller, G. (1998). An Interest Group Theory of Central Bank Independence. The Journal Of Legal Studies, 27(2), 433-453. 
Mulligan, C. \& Sala-i-Martin, X. (1999). Gerontocracy, retirement and social security. (NBER Working Paper 7119). Cambridge, MA: National Bureau of Economic Research.

Mulligan, C., \& Sala-i-Martin, X. (2003). Social Security, Retirement, and the Single-Mindedness of the Electorate. (NBER Working Paper 9691). Cambridge, MA: National Bureau of Economic Research.

Nordhaus, W. (1975). The Political Business Cycle. The Review Of Economic Studies, 42(2), 169-190.

Norpoth, H. (1996). Presidents and the Prospective Voter. The Journal Of Politics, 58(3), 776-792.

OECD. (1996). Ageing in OECD Countries: A Critical Policy Challenge. Paris: OECD.

OECD (2013) Pensions at a Glance. OECD report, Paris. Accessed at:

http://www.oecd.org/pensions/public-pensions/OECDPensionsAtAGlance2013.pdf

Page, B., \& Shapiro, R. (1983). Effects of Public Opinion on Policy. American Political Science Review, 77(01), 175-190.

Paldam, M. (1991). How robust is the vote function? A study of seventeen nations over four decades. In H. Norpoth, M.S. Lewis-Beck, \& J. D. Lafay (Eds.), Economics and Politics: The Calculus of Support. Ann Arbor: University of Michigan Press. 443-67.

Pamp, O. (2015). Political Preferences and the Aging of Populations. New York: Springer VS.

Pampel, F., \& Williamson, J. (1985). Age Structure, Politics, and Cross-National Patterns of Public Pension Expenditures. American Sociological Review, 50(6), 782-798.

Pampel, F., \& Williamson, J. (1989). Age, class, politics and the welfare state. Cambridge: Cambridge University Press.

Persson, T., \& Tabellini, G. (2000). Political Economics. Cambridge: MIT Press.

Pierson, P. (1994). Dismantling the Welfare State? Reagan, Thatcher and the Politics of Retrenchment. Cambridge, UK: Cambridge University Press.

Pierson, P. (1998). Irresistible forces, immovable objects: post-industrial welfare states confront permanent austerity. Journal Of European Public Policy, 5(4), 539-560.

Polillo, S., \& Guillén, M. (2005). Globalization Pressures and the State: The Worldwide Spread of Central Bank Independence. American Journal Of Sociology, 110(6), 1764-1802.

Posen, A. (1993). Why Central Bank Independence Does Not Cause Low Inflation: There is No Institutional Fix for Politics. In R. O'Brien (Ed.), Finance and the International Economy. Oxford, UK: Oxford University Press.

Posen, A. (1995). Declarations Are Not Enough: Financial Sector Sources of Central Bank Independence. In B. Bernanke \& J. Rotemberg, NBER Macroeconomics Annual 1995 (pp. 255-295). Cambridge, MA: MIT Press.

Posen, A. (1998). Central bank independence and disinflationary credibility: a missing link? Oxford Economic Papers, 50(3), 335-359. 
Poterba, J. M. (1998), Demographic Change, Intergenerational Linkages, and Public Education. American Economic Review, 88, 315-320.

Rehm, P. (2016). Risk inequality and welfare states: Social Policy Preferences, Development, and Dynamics. Cambridge: Cambridge University Press.

Rogoff, K. \& Sibert, A. (1988). Elections and Macroeconomic Policy Cycles. The Review Of Economic Studies, 55(1), 1-19.

Rose, A. M. (1965). The subculture of ageing: a framework for research in social gerontology. In A. M. Rose \& W. A. Peterson (Eds.), Older People and their Social World: The Sub-Culture of the Aging. Philadelphia: F.A. Davies Co.

Rueda, D. (2006). Social Democracy and Active Labour-Market Policies: Insiders, Outsiders and the Politics of Employment Promotion. British Journal Of Political Science, 36(03), 385-406.

Sabbagh, C., \& Vanhuysse, P. (2006). Exploring Attitudes Towards the Welfare State: Students' Views in Eight Democracies. Journal Of Social Policy, 35(04), 607.

Scharpf, F. (1987). A Game-Theoretical Interpretation of Inflation and Unemployment in Western Europe. Journal Of Public Policy, 7(03), 227-257.

Scheve, K. (2004). Public Inflation Aversion and the Political Economy of Macroeconomic Policymaking. International Organization, 58(01), 1-34.

Schmitt, H., Scholz, E., Leim, I., \& Moschner, M. GESIS Datarachiv. (2008). The Mannheim Eurobarometer Trend File 1970-2002 (Version 2.0.1).

Shiller, R. (1997). Why Do People Dislike Inflation?. In C. Romer \& D. Romer,(Eds.) Reducing Inflation: Motivation and Strategy (pp. 13 - 70). Chicago: University of Chicago Press.

Sinn, H., \& Uebelmesser, S. (2002). Pensions and the path to gerontocracy in Germany. European Journal Of Political Economy, 19(1), 153-158.

Sørensen, R. (2013). Does aging affect preferences for welfare spending? A study of peoples' spending preferences in 22 countries, 1985-2006. European Journal Of Political Economy, 29, 259-271.

Tepe, M., \& Vanhuysse, P. (2009). Are Aging OECD Welfare States on the Path to Gerontocracy?. Journal Of Public Policy, 29(01), 1-28.

Tepe, M., \& Vanhuysse, P. (2010). Elderly bias, new social risks and social spending: change and timing in eight programmes across four worlds of welfare, 1980-2003. Journal Of European Social Policy, 20(3), 217-234.

Tilley, J. (2002). Political generations and partisanship in the UK, 1964-1997. Journal Of The Royal Statistical Society: Series A (Statistics In Society), 165(1), 121-135.

Uren, D. (2007). Talkback tactic wins PM his voters. The Australian.

Visser, J. Amsterdam Institute for Advanced Labour Studies AIAS. University of Amsterdam. (2013). Database on Institutional Characteristics of Trade Unions, Wage Setting, State Intervention and Social 
Pacts, 1960-2011 (Version 4). Retrieved from http://uva-aias.net/en/ictwss

Vlandas, T. (2013a) Mixing apples with oranges? Partisanship and active labour market policies in Europe. Journal of European Social Policy 23(3), 3-20.

Vlandas, T. (2013b) The Politics of Temporary Work Deregulation in Europe: Solving the French Puzzle. Politics \& Society 41(3), 425-460.

Volkens, A., Lehmann, P., Merz, N., Regel, S., Werner, A. Wissenschaftszentrum Berlin fürSozialforschung (WZB). (2014) The Manifesto Data Collection. Manifesto Project (Version 2014a).

Whiteley, P., Syed, P., \& Richardson, J. (1994). True blues: The politics of British conservative party members. Oxford: Clarendon Press

Wilson, G. (1991). Models of Ageing and their Relation to Policy Formation and Service Provision. Policy \& Politics, 19(1), 37-48.

Wlezien, C., \& Soroka, S.- N. (2007). The relationship beween public opinion and policy, in R. J. Dalton and H-D. Klingemann (eds), The Oxford Handbook of Political Behaviour (pp. 799-817). Oxford: Oxford University Press.

Yoon, J.-W., Kim, J., \& Lee, J. (2014). Impact of Demographic Changes on Inflation and the Macroeconomy (IMF Working Paper 14/210). Washington, DC: International Monetary Fund

Zysman, J. (1977). The French state in the international economy. International Organization, 31(04), 839-877. 